Article

\title{
Land-Acquisition and Resettlement (LAR) Conflicts: A Perspective of Spatial Injustice of Urban Public Resources Allocation
}

\author{
Jinxia Zhu ${ }^{1}$, Qian Xu ${ }^{2}$, Yi Pan ${ }^{1}$, Lefeng Qiu ${ }^{1}$, Yi Peng ${ }^{2}$ and Haijun Bao ${ }^{2, *}$ \\ 1 Institute of Land and Urban-Rural Development, Zhejiang University of Finance \& Economics, \\ Hangzhou 310018, China; jxzhu@zufe.edu.cn (J.Z.); ypangis@zufe.edu.cn (Y.P.); qiulefeng@zufe.edu.cn (L.Q.) \\ 2 School of Public Administration, Zhejiang University of Finance \& Economics, Hangzhou 310018, China; \\ xuqian.zufe@foxmail.com (Q.X.); pengyihz@zufe.edu.cn (Y.P.) \\ * Correspondence: baohaijun@zufe.edu.cn
}

Received: 30 January 2018; Accepted: 15 March 2018; Published: 20 March 2018

\begin{abstract}
Land acquisition and resettlement (LAR) is an important step in urban development. As one of the 'externalities of development', LAR conflicts have affected social stability and development in rural areas of China. With social conflict research shifting from value identity to resource allocation, few studies have examined the relationship between the spatial injustice of urban public resources and LAR conflict. To mitigate this research gap and formulate effective policies, this study aims to reinterpret the obstacles of LAR conflicts from the perspective of the spatial injustice of urban public facilities allocation in Hangzhou City by examining 195 administrative litigation cases. Spatial accessibility was used for estimating the spatial justice of urban public resources allocation. A classification and regression tree (CART) model was applied to identify the advantage and disadvantage factors behind LAR conflict, and explored the logical and structural relationships among these factors. Results showed that a spatial mismatch between the spatial behavior preferences of human activity and the spatial injustice of urban public resources allocation had significantly accelerated LAR conflicts. When the spatial behavior preferences of human activity and spatial distribution of urban public resources correspond to each other pre- and after LAR, basic rights to social space are safeguarded and various groups can equitably share spatial resources. There are no conflicts. Conversely, respondents expressed a high level of dissatisfaction in comparison to their pre-LAR conditions, and LAR conflict undeniably occurs. This approach also proposes some good LAR policies by regulating the spatial injustice of urban public resources allocation associated with LAR with the aim of long-term urban sustainable development for Hangzhou.
\end{abstract}

Keywords: land acquisition and resettlement (LAR); conflict; spatial justice; spatial mismatch; classification and regression tree (CART)

\section{Introduction}

The contradiction between urban land expansion and farming land loss is an increasing challenge of the urbanization process [1,2], which has increased dramatically during the past 10 years and appears to be accelerating [3-5]. In the process of the 'eating up' of rural land, various forms of land requisition have emerged [6-10]. It has been reported that more than 250-300 million people worldwide have been displaced over the past 20 years [11]. In China, the estimated number is 40 to 50 million and it will reach 110 million by 2030 [12]. Moreover, there is more than $90 \%$ illegal land acquisition by local governments in several cities [13], which have caused related legal and land-acquisition and resettlement (LAR) conflicts $[13,14]$. In 2005 , more than $65 \%$ of mass incidents in rural China were reportedly from land expropriation, such as police responded by opening fire on 
demonstrators in the village of Dongzhou, Guangdong, China [15]. In 2010, more than 40,000 mass incidents occured in China were caused by LAR conflict $[16,17]$. According to official statistics of the Ministry of Land and Resources in 2004, more than $40 \%$ of the petitions filed by peasants were related to illegal land acquisitions and land seizures [17], and the number was approximately $60 \%$ in 2011 [18]. LAR conflict has become one of the 'externalities of development' that affects social stability and development in rural areas of China $[6-8,19,20]$. Local government should pay more attention to elevating levels of social sustainability by exploring the obstacle of LAR conflict.

Many scholars have conducted extensive studies on the root causes of LAR conflicts [21,22]. Land issues involve multiple disciplines, and different scholars have conducted research on various aspects of land conflicts according to the paradigms of different disciplines [21]. Demography suggests that the increased demographic demands are the main driving force of the generation and development of conflicts [23-26]. Sociology attributes conflicts to the influence of various factors, such as economic development, economic restructuring, and policies associated with technological progress [27-29]. The institutional economics literature notes that conflicts are based on economic growth and the economic mode, environmental management system, and differences between urban and rural development formed under a dual rural-urban system. The institutional economics literature also indicates that the lack of policies and regulations, as well as induction from the social environment, accelerates the generation and development of conflicts [28,30-32]. Jurisprudence research focuses on the legal analysis of LAR law and power conflicts to assess the driving force of LAR conflicts [32,33]. Land-management scholars emphasize the use of conflict-management practice technology for guidance while studying the incentives of land conflicts $[13,34]$.

More important, modern social conflict theory has shifted the research from value identity to resource allocation. As one of the most important outputs of urbanization, the unequal spatial distribution of a city service system between groups is the major cause of social conflict [35]. Spatial justice is the socio-spatial distribution of multiple spatial deprivations [36], which provide a useful way for relating locational discrimination and social justice and have been widely used for urban public resources inequalities analysis [37]. In the context of geography's 'cultural turn' and sociology's 'spatial turn', the issue of spatial justice of resource allocation has entered the field of space research [38]. While there are many works studying the spatial injustice of the distribution of urban public resources, such as green space [39-44], amenities [44], energy justice [45,46], health care [47-49], schools [50-54], shops [2,55], public playgrounds [56,57], neighbourhood facilities [58], and transportation [59-62], much empirical research on the spatial distribution of urban public services has focused on defining and measuring what equity is and determining influence factors $[63,64]$. Spatial justice has been one of the significant challenges for China's political system [65]. As LAR is a big source of social conflict in China, can LAR conflict successfully be immune from spatial injustice in urban public resources? This question should be addressed first. However, while most of the existing LAR conflict studies have made considerable efforts, including establishing new practical understandings of land markers, legislating new laws, increasing compensation, standards, and punishing corrupt officials, there are few studies employing the social space perspective to analyze the impact of spatial injustice of urban public resources allocation on the accompanying LAR conflict. Additionally, it makes little sense to discuss the relationship between the spatial justice of urban public resource allocation and LAR conflict for a single type of urban facility [40]. Public facility allocation analysis is prone to ignore the relationship between different public facilities, which would fail to explore the inter/intra effects of overall public facilities on the preference of urban residents, and to consider the interaction among various urban public resource allocation, even their influence on LAR conflict.

Therefore, it is useful to take the spatial justice of urban public resources allocation as the priority value in the decision process of urban public policy, such as LAR policy $[66,67]$. The present study attempts to interpret the relationship between the spatial injustice of various urban public resources allocations and LAR conflict. We use the conceptual lens of spatial justice of urban public resources allocation to explore the core influencing factors of LAR conflict. A classification and regression 
tree (CART) model is used to investigate the critical influence of the independent variables of LAR conflict and explore the interactive relationship from the perspective of spatial injustice of urban public resource allocation. This research takes the city of Hangzhou as the case area for the investigation by examining 195 administrative litigation cases. The spatial justice of urban public resources allocation was used to probe the management of LAR by urban planners and policymakers. Better management and control of urban public resources allocation and LAR policies are proposed for urban planners and policymakers in order to advance intensive and sustainable development in China.

\section{Materials and Method}

\subsection{Study Area and Data Collection}

The study area is located in the north of Zhejiang Province, China (Figure 1). Hangzhou City has a variety of land-cover types, including agricultural fields, fallow land, water surface, and urban areas. This study covered an area of $728 \mathrm{~km}^{2}$ and the registered permanent residents were 3.56 million people. The local GDP per capital at the end of 2010 was nearly 109,708 RMB Yuan. As a result of the implementation of "city internationalization" (i.e., the policies of one primary city, three associate districts, and six areas; 21 large urban cities and 100 city complexes; city networking; and metropolis construction) and the rapid progress of key projects (e.g., Qianjiang New City, subway and Olympic Expo Center), Hangzhou City's land expropriation and LAR projects have exhibited substantial growth. Hangzhou Municipal Bureau of Land Resource Administration issued nine "LAR permits" from February to April 2013. Five of these permits are in Jianggan District, three are in Gongshu District, and one is in West Lake District. There have been large number of LAR conflicts in Hangzhou in the recent years such that local government has proposed numerous policies and approaches to relieve LAR conflicts $[13,68]$. However, the legal and administrative cases related to these conflicts have become the focus of mass social events.

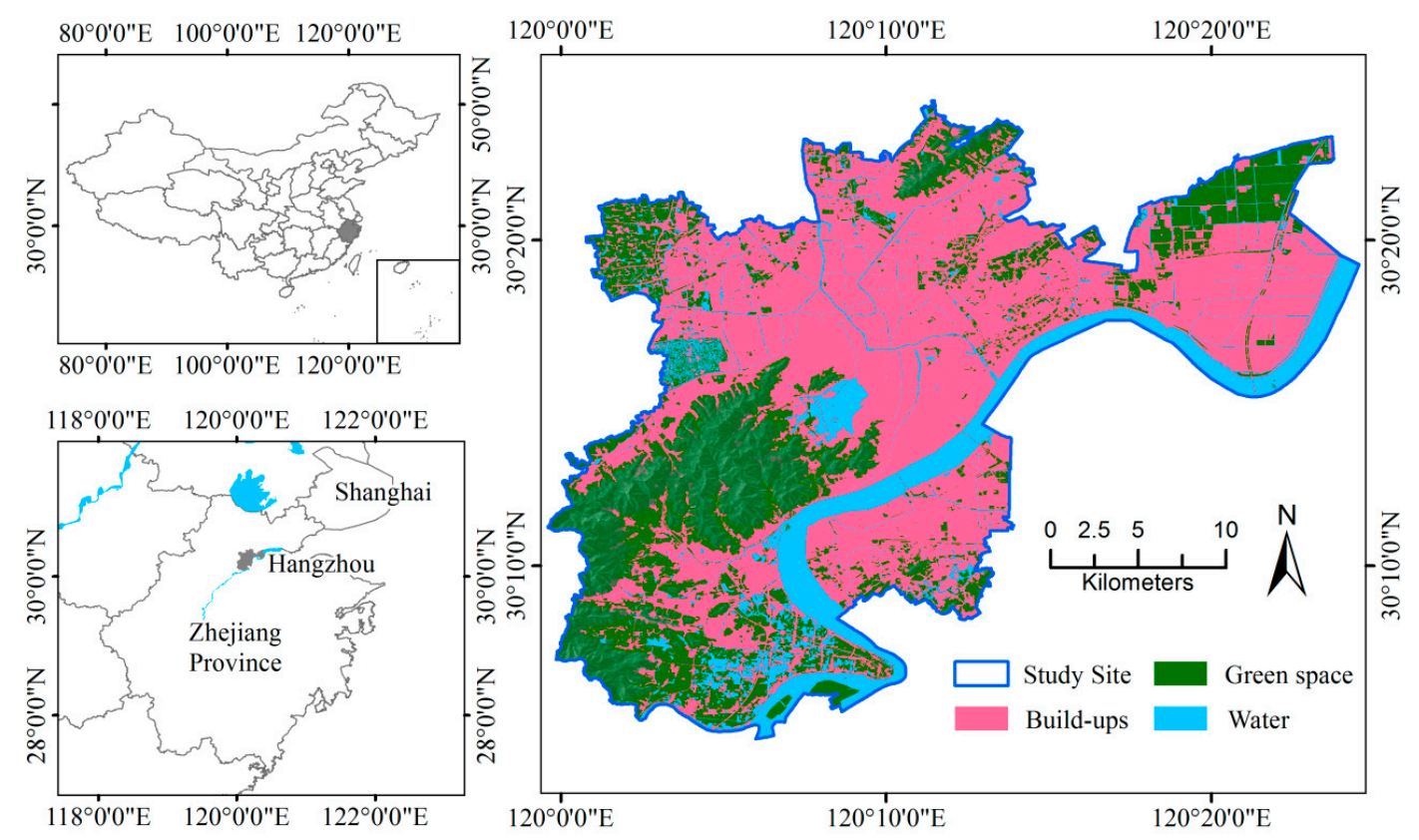

Figure 1. Location of study area.

Disputes over LAR occur frequently in Hangzhou. Existing studies have reported that the major stakeholders are local government departments and farmers who have lost land. Therefore, this research merely considers administrative litigation, in which the local government department is the defendant [69]. The current study, therefore, selects relevant judgment documents from the 
database of China Judgments Online, which is open-access and contains sufficient information [69]. The keywords "administrative case", "Hangzhou", and "land acquisition or land resettlement" were used to search for relevant verdict documents. Case causal data and judgment documents data refer to the actual judgment, relevant approval documents, and administrative behavior records. The areas in Hangzhou City that experienced LAR in 2014 and 2015 were searched based on the LAR notices issued by the Hangzhou Housing Security and Management Bureau. By excluding all irrelevant and duplicated cases, a total of 195 judgment documents were eventually identified as decisions regarding LAR cases, among which 155 were randomly selected as training samples and 40 were used to verify simulation accuracy. Approximately 150 non-conflict samples were selected among all the areas in Hangzhou with LAR. Of these total samples, 120 are training samples and 30 are test samples.

\subsection{Variables and Measurement}

A reasonable level of spatial accessibility is unanimously considered to be an essential right in terms of spatial justice goals $[44,54,58-64,70-73]$. The sensitive variables of urban public resources are defined as less accessibility based on a literature review [38,42-44,47-63]. These factors fall within the scope of essential public services and facilities, economic public services and facilities, and social public services and facilities. A total of 10 independent variables are used in this study (Table 1). The consideration of LAR conflict indicators is typically founded on practical understandings; semi-structured interviews were carried out to develop an optional list of indicator levels [74,75]. In order to check the robustness of the indicator level list, open discussion about LAR was encouraged. This was followed by modifications until these interviewees reached an agreement on the indicator level list. According to the relevant literature and information provided by residents during field interviews, the present study equally divides the proximity data into five levels (i.e., 1 to 5 , which represent low to high, respectively) (see Table 1). In this study, there were five categories of public facilities (e.g., green space, educational, health, sport, and cultural/religious). The geographical location information of the 10 variables within the range of Hangzhou City in 2015 was obtained through Google Maps. A $100 \mathrm{~m}$ $\times 100 \mathrm{~m}$ geographical grid was adopted as the basis for model calibration and calculation. ArcGIS 9.3 was used to calculate the accessibility data of the essential, economic, and social public services, as well as to obtain a property database of conflict and non-conflict samples (Figure 2).

\subsubsection{Transportation Facilities}

Transportation facilities are important urban public resources. Metro and bus stations are the primary choice for the daily travel of residents. These transportation modes are evident in improving the travel efficiency and quality of life of residents. These factors reflect the fact that residents have the potential to live near metro and bus stations. Elevated roads and highways are prone to result in the infringement of the surrounding residents' right of space. In addition, elevated roads and highways have brought immense convenience to the lives of residents. These factors indicate that transportation facilities allocation is imbalanced and the accessibility of transportation facilities would affect LAR conflicts.

\subsubsection{Medical Facilities}

The uneven distribution of medical resources and difficulties in the realization of the right to seek medical treatment result in unfair social problems. Hangzhou City has 18 AAA-level hospitals, although most of them are densely distributed in the downtown area with uneven spatial distribution. Thus, the "center-periphery" structure of medical facilities contributes to the spatial injustice of medical resources allocation, which has affected the daily life of suburban residents. In addition, people are resistant to living near the hospital due to China's culture. The imbalanced medical facilities allocation would influence choices and judgments in LAR conflicts. 
Table 1. Characteristics of indicators and descriptive analysis.

\begin{tabular}{|c|c|c|c|c|}
\hline \multirow{2}{*}{$\begin{array}{c}\text { Abbreviation } \\
\text { Land-acquisition and Resettlement Conflict }\end{array}$} & \multicolumn{2}{|c|}{ Measurement } & \multirow{2}{*}{$\begin{array}{c}\text { Variables } \\
\text { LAR }\end{array}$} & \multirow[t]{2}{*}{ Scale } \\
\hline & LAR Conflict & Conflict $=1$; no-Conflict $=0$ & & \\
\hline \multirow{20}{*}{ Essential public services and facilities } & \multirow{5}{*}{ Bus station } & \multirow{5}{*}{ Distance to a bus station (BS) } & BS1 & $\leq 200 \mathrm{~m}$ \\
\hline & & & BS2 & $200-400 \mathrm{~m}$ \\
\hline & & & BS3 & $400-600 \mathrm{~m}$ \\
\hline & & & BS4 & $600-800 \mathrm{~m}$ \\
\hline & & & BS5 & $\geq 800 \mathrm{~m}$ \\
\hline & \multirow{5}{*}{ Metro station } & \multirow{5}{*}{ Distance to a metro station (SB) } & SB1 & $\leq 2000 \mathrm{~m}$ \\
\hline & & & SB2 & $2000-4000 \mathrm{~m}$ \\
\hline & & & SB3 & $4000-6000 \mathrm{~m}$ \\
\hline & & & SB4 & $6000-8000 \mathrm{~m}$ \\
\hline & & & SB5 & $\geq 8000 \mathrm{~m}$ \\
\hline & \multirow{5}{*}{ Elevated roads } & \multirow{5}{*}{ Distance to elevated roads (ER) } & ER1 & $\leq 1000 \mathrm{~m}$ \\
\hline & & & ER2 & $1000-2000 \mathrm{~m}$ \\
\hline & & & ER3 & $2000-3000 \mathrm{~m}$ \\
\hline & & & ER4 & $3000-4000 \mathrm{~m}$ \\
\hline & & & ER5 & $\geq 400 \mathrm{~m}$ \\
\hline & \multirow{5}{*}{ Highway } & \multirow{5}{*}{ Distance to a highway (HW) } & HW1 & $\leq 1000 \mathrm{~m}$ \\
\hline & & & HW2 & $1000-2000 \mathrm{~m}$ \\
\hline & & & HW3 & $2000-3000 \mathrm{~m}$ \\
\hline & & & HW4 & $3000-4000 \mathrm{~m}$ \\
\hline & & & HW5 & $\geq 4000 \mathrm{~m}$ \\
\hline \multirow{10}{*}{ Economic public services and facilities } & \multirow{5}{*}{ CBD } & \multirow{5}{*}{ Distance to a CBD (CBD) } & CBD1 & $\leq 2000 \mathrm{~m}$ \\
\hline & & & CBD2 & $2000-4000 \mathrm{~m}$ \\
\hline & & & CBD3 & $4000-6000 \mathrm{~m}$ \\
\hline & & & CBD4 & $6000-8000 \mathrm{~m}$ \\
\hline & & & CBD5 & $\geq 8000 \mathrm{~m}$ \\
\hline & \multirow{5}{*}{ Supermarket } & \multirow{5}{*}{ Distance to a supermarket (SM) } & SM1 & $\leq 600 \mathrm{~m}$ \\
\hline & & & SM2 & $600-1200 \mathrm{~m}$ \\
\hline & & & SM3 & $1200-1800 \mathrm{~m}$ \\
\hline & & & SM4 & $1800-2400 \mathrm{~m}$ \\
\hline & & & SM5 & $\geq 2400 \mathrm{~m}$ \\
\hline \multirow{20}{*}{ Social public services and facilities } & \multirow{5}{*}{ School } & \multirow{5}{*}{ Distance to a school (SC) } & SC1 & $\leq 200 \mathrm{~m}$ \\
\hline & & & $\mathrm{SC} 2$ & $200-400 \mathrm{~m}$ \\
\hline & & & SC3 & $400-600 \mathrm{~m}$ \\
\hline & & & SC4 & $600-800 \mathrm{~m}$ \\
\hline & & & SC5 & $\geq 800 \mathrm{~m}$ \\
\hline & & & HP1 & $\leq 200 \mathrm{~m}$ \\
\hline & & & HP2 & $200-400 \mathrm{~m}$ \\
\hline & Hospital & Distance to a hospital (HP) & HP3 & $400-600 \mathrm{~m}$ \\
\hline & & & $\mathrm{HP} 4$ & $600-800 \mathrm{~m}$ \\
\hline & & & HP5 & $\geq 800 \mathrm{~m}$ \\
\hline & & & RV1 & $\leq 300 \mathrm{~m}$ \\
\hline & & & RV2 & $300-600 \mathrm{~m}$ \\
\hline & River & Distance to a river (RV) & RV3 & $600-900 \mathrm{~m}$ \\
\hline & & & RV4 & $900-1200 \mathrm{~m}$ \\
\hline & & & RV5 & $\geq 1200 \mathrm{~m}$ \\
\hline & & & PK1 & $\leq 150 \mathrm{~m}$ \\
\hline & & & PK2 & $150-300 \mathrm{~m}$ \\
\hline & Park & Distance to a park (PK) & PK3 & $300-450 \mathrm{~m}$ \\
\hline & & & PK4 & $450-600 \mathrm{~m}$ \\
\hline & & & PK5 & $\geq 600 \mathrm{~m}$ \\
\hline
\end{tabular}




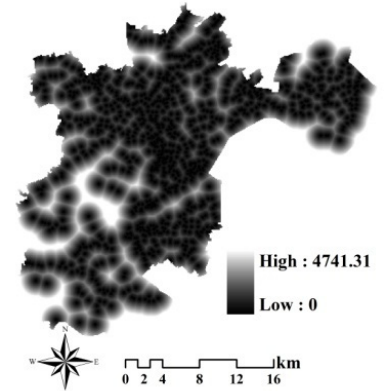

(a) BS

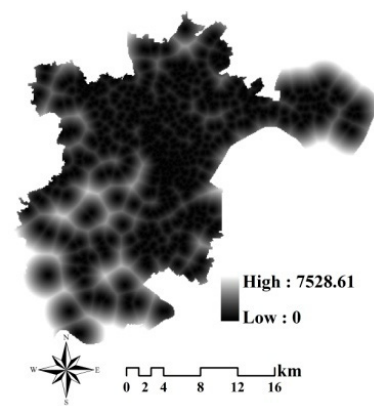

(d) $\mathrm{H}$

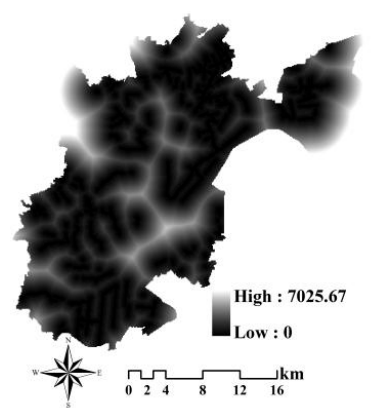

(g) $\mathrm{R}$

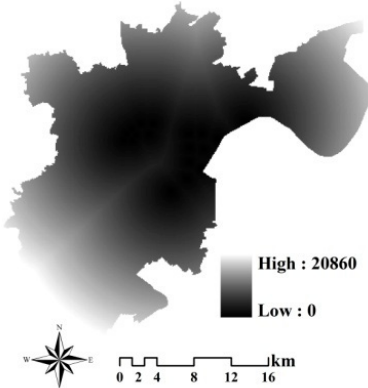

(b) CBD

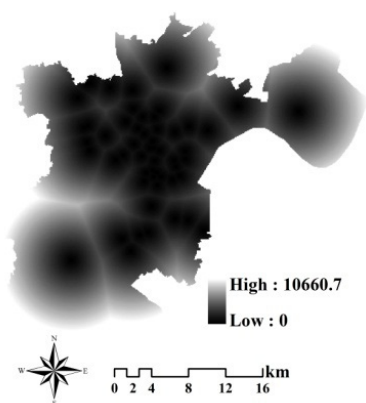

(e) $\mathrm{SM}$

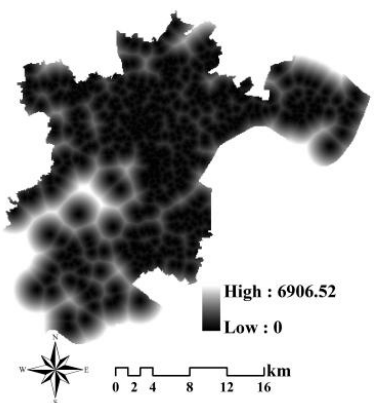

(h) SC

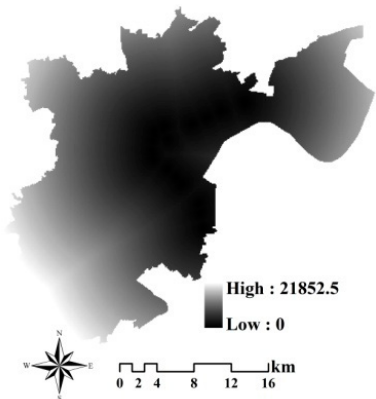

(j) SB

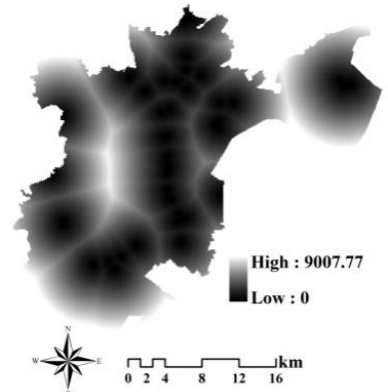

(c) $\mathrm{F}$

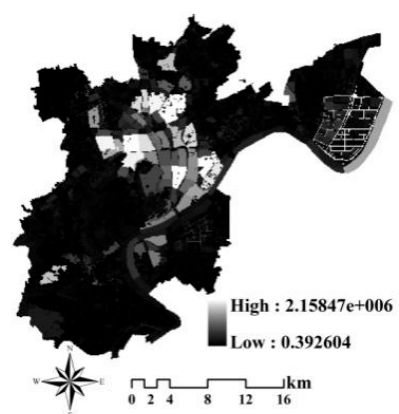

(f) PK

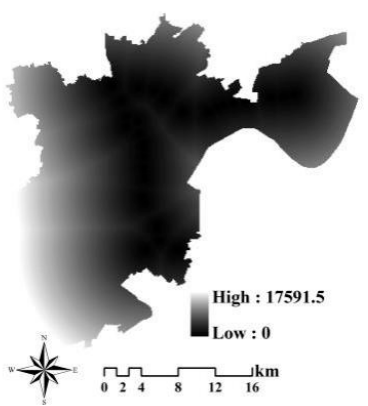

(i) $\mathrm{V}$

\subsubsection{Leisure Facilities}

Consumer demand for leisure facilities has increased because of the improvement in the standard of living of Zhejiang Province residents. Parks, green spaces, and squares have significant positive externalities and higher leisure-function value. The spatial accessibility of leisure facilities has a significant effect on the public's physical and psychological health. Due to the different accessibility of public resources, people have different space property rights. The accessibility to rivers and parks are 
criteria for the spatial justice of leisure facilities' allocation. Imbalanced leisure facilities' allocation would influence choices and judgments in LAR conflict.

\subsubsection{Educational Facilities}

There is a problem of an uneven distribution of educational resources in the provinces, cities and regions. Hangzhou City has high-quality and extensive educational resources. However, most of these resources are located within the old city with a relatively unbalanced spatial distribution. Accordingly, a distribution trend of the concentration of educational facilities is apparent. Educational policies, such as marking out school districts and selecting schools based on the locations of residences, have resulted in the particular importance of the geographical conditions of local residences in school preference. Thus, school accessibility, which can be individually perceived by different residents, reflects the rational judgment of residents about the spatial justice of educational facilities' allocation. Imbalanced educational facilities' allocation would influence choices and judgments in LAR conflict.

\subsubsection{Shopping Facilities}

Supermarkets, shopping malls and CBD service provide everyday commodities for residents. The cost of shopping includes not only the price of goods but also the cost of time and distance, which makes the geographical conditions of the surrounding residents superior. Consumers in the outer radius will pay a higher cost for the same resources, which is also a type of unfair treatment. Shopping facilities are imbalanced and accessibility to shopping facilities attracts the attention of residents. Imbalanced shopping facilities' allocation would influence choices and judgments in LAR conflict.

\subsection{Classification and Regression Tree (CART) Model}

The CART model was used to explore the sources of LAR conflicts from the accessibility of urban public resources. During the successive subdivision stage, a complex decision is split into several simpler decisions. The influencing factors of LAR conflict are set up as the predictor variables. The CART analysis shows that the influence of the independent variables of conflict can be evaluated, and the correlation among the various influencing factors can be analyzed using a multi-level staircase structure. This study used 155 training samples for the CART analysis, which was conducted using SPSS18.

\section{Results and Findings}

3.1. The Relationship between the Spatial Injustice of Urban Public Resources Allocation and Land-Acquisition and Resettlement (LAR) Conflict

Table 2 shows the relationships between the accessibility of urban public resources variables and the LAR conflict indicator. The cumulative pattern decision-making tree of the LAR conflicts, which comprises 18 nodes, is acquired through the CART simulation. Therefore, the spatial injustice of urban public resources allocation, such as the disadvantageous accessibility of elevated roads, hospitals, rivers, and schools, is a major sources of LAR conflicts. The simulation accuracy reaches $80.5 \%$. The fact that six factors are not selected by the classification patterns does not mean that these factors have no effect on LAR conflicts. This result merely indicates that the extent of their influence is minimal compared with the selected four variables involved in the classification patterns. The pattern tree suggests the complexity and comprehensiveness of the root causes of LAR conflicts from the perspective of the spatial injustice of urban public resources allocation. First, the accessibility of elevated roads is at the top layer, which is the most important root cause of LAR conflicts. The demarcation point is at $1 \mathrm{~km}$. The people who live within $1 \mathrm{~km}$ of elevated roads have a strong perception of LAR. Imbalanced transportation facilities is the main source of LAR conflict. Second, the accessibility of rivers is at the immediate layer, which has a good corresponding relationship with 
LAR conflicts. The $600 \mathrm{~m}$ service radius of rivers shows the best correlation with the comfort of the natural environment, which are the ecologically advantaged group areas. Leisure facilities within the $600 \mathrm{~m}$ service radius is spatial injustice and residents within $600 \mathrm{~m}$ of rivers have the potential to resist the LAR. Leisure facilities allocation is another source of LAR conflict. Third, the accessibility of educational resources is at the bottom layer, and educational facilities allocation is another root cause of LAR conflicts. The residents within a $400 \mathrm{~m}$ radius of schools are the advantaged group. LAR conflicts are likely to occur if these residents are deprived of educational advantages. Finally, the accessibility of medical resources is also at the bottom layer. Medical facilities allocation has a significant influence on LAR conflicts. Places within $200 \mathrm{~m}$ of a hospital can provide spatial justice and there are no LAR conflicts within these areas.

Table 2. Rules for predicting classes of land-acquisition and resettlement (LAR) conflict.

\begin{tabular}{cl}
\hline Conflict Class & \multicolumn{1}{c}{ Rules } \\
\hline \multirow{2}{*}{ Conflict $(\mathrm{C} 1)$} & Rule1: $(\mathrm{ER} \leq 2 \mathrm{~km}) \&(\mathrm{RV} \leq 300 \mathrm{~m}) \&(\mathrm{HP} \leq 200 \mathrm{~m}) \&(\mathrm{SC} \leq 400 \mathrm{~m})$ \\
& Rule 2: $(1 \mathrm{~km} \leq \mathrm{ER}<2 \mathrm{~km}) \&(300 \mathrm{~m}<\mathrm{RV} \leq 600 \mathrm{~m}) \&(\mathrm{SC} \leq 200 \mathrm{~m}) \&(200 \mathrm{~m}<\mathrm{HP} \leq 400 \mathrm{~m})$ \\
\hline No conflict $(\mathrm{C} 2)$ & Rule 1: $(\mathrm{ER}<1 \mathrm{~km}) \&(\mathrm{HP} \leq 200 \mathrm{~m}) \&(\mathrm{SC} \geq 800 \mathrm{~m}) \&(\mathrm{RV}>600 \mathrm{~m})$ \\
\hline
\end{tabular}

\subsection{The Relative Importance of Urban Public Resources Allocation}

The CART approach provides the relative importance of each independent environmental variable. The error rate was used to rank the relative importance of indicators. The key factors were listed on the top and should be paid more attention. The CART approach cannot provide a quantitative evaluation despite the offer of relative importance parameters. The 155 training samples were applied to evaluate the relative importance of the selected four variables (i.e., distance to elevated roads (ER), distance to a hospital (HP), distance to a river (RV), and distance to a school (SC). This study adopted each environmental variable's training accuracy to quantitatively evaluate each participating independent variable's importance with regard to the effect of LAR conflicts. Table 3 demonstrates the results of CART with a different tree model. As shown in Table 3, the number of nodes up to 24 indicates that the CART has a complex structure. The variables related to ER, RV and HP were the most significant factor in classifying LAR conflicts. This case is followed by the importance of two dependent variables (i.e., ER and HP), with the error rate of $36.1 \%$. While the error rate of single variable ER increased to $29.1 \%$, indicating that the variable ER had the significant influence on LAR conflict followed by RV, HP and SC. Therefore, the spatial justice of urban public resources allocation has a good relationship with LAR conflicts. The accessibility to elevated roads is the most important factor influencing LAR conflict, followed by the accessibility to water resources and the accessibility to medical resources. Thus, imbalanced transportation facilities are the main cause of LAR conflict, followed by imbalanced leisure facilities and medical facilities.

Table 3. Error rate and number of nodes with different tree model in the classification and regression tree (CART).

\begin{tabular}{cccc}
\hline Tree Model & Variable & Error Rate & Number of Nodes \\
\hline \multirow{4}{*}{ Group 1 } & Missing HP, RV, SC & 33.6 & 6 \\
& Missing ER, RV, SC & 33.9 & 6 \\
& Missing ER, HP, RV & 44.5 & 4 \\
& Missing ER, HP, SC & 38.9 & 8 \\
\hline \multirow{5}{*}{ Group 2 } & Missing RV, SC & 28.4 & 22 \\
& Missing HP, SC & 23.6 & 24 \\
& Missing HP, RV & 33.9 & 8 \\
& Missing ER, SC & 29.8 & 24 \\
& Missing ER, RV & 32.5 & 16 \\
& Missing ER, HP & 36.1 & 14 \\
\hline \multirow{5}{*}{ Group 3 } & Missing SC & 20.7 & 18 \\
& Missing ER & 29.1 & 16 \\
& Missing RV & 28.6 & 24 \\
\hline Group 4 & Missing HP & 20.9 & 18 \\
\hline
\end{tabular}




\section{Discussion}

\subsection{LAR Conflict Is not Immune from the Spatial Injustice of Urban Public Resources Allocation}

Spatial justice implies that there is an even distribution of urban public resources in relation to the preferences of each resident [76]. Here, in our study, the local governments and farmers act sequentially in the conflict. Conflict lies in the spatial mismatch between spatial behavior preferences of human activity and the spatial distribution of urban public resources pre- and after LAR. Behavioral economics focuses on the basic characteristics of 'loss aversion' of people's preferences. Generally, for the same loss and gain, people pay more attention to the loss. People experienced LAR as a big risk of losing their own housing environment, such as leisure facilities and educational facilities. Importantly, most people want to equitably share the spatial resources, and enjoy the city's basic public services. When the spatial behavior preferences of human activity and spatial distribution of resources correspond to each other pre- and after LAR, the basic rights of social space are safeguarded and various groups can equitably share spatial resources in the social space. Thus, the spatial justice of urban public resources are not prone to conflicts. Conversely, respondents expressed a high level of dissatisfaction in comparison to their pre-LAR conditions and then a LAR conflict happened As shown in our study, areas within a $1 \mathrm{~km}$ radius of elevated roads and areas within a $200 \mathrm{~m}$ range of hospitals are characterized by the spatial inequality of urban public facilities allocation. They would be away from the spatial deprivation after LAR and there is no LAR conflict. Residents within a $600 \mathrm{~m}$ radius from a river and residents within a $400 \mathrm{~m}$ range from schools are sensitive allocation groups who must face the spatial deprivation of water resources and educational resources. They may no longer have access to share urban public resources, and then LAR conflict undeniably occurs.

\subsection{Factors of LAR Conflicts from the Perspective of Spatial Injustice of Urban Public Resources Allocation}

Table 3 indicates that imbalanced allocation of transportation facilities (elevated roads) is the most important factor of LAR conflict (mis-classification error rate of ER: 29.1\%). In this study, districts within $1 \mathrm{~km}$ of elevated roads are more likely to have no LAR conflict. In this study, elevated roads face immense traffic pressure because Hangzhou City has an urban rapid transit system and main roads. The AutoNavi map in the 2015 Transpiration Analysis Report of China's Major Cities notes that traffic jams in Hangzhou City last for an average of seven hours per day. Due to the traffic jams and drastically increased travel times on routes along the elevated roads, residents think that environmental pollution resulting from vehicle exhaust and dust negatively affects their health [76]. In addition, noise that radiates from the elevated roads is another inevitable nuisance to the nearby residents [77,78]. Although elevated roads have comprehensive shelter equipment and environmental protection measures, which can provide convenient travel conditions for nearby residents, the construction of several elevated roads has different levels of negative effects on a residence's privacy and view [79]. This activity violates the human desire for separate space and to be alone in the environment, as well as the desire for a sense of security. People living within $1 \mathrm{~km}$ of elevated road do feel they can benefit from LAR. This indicates that characterizing the spatial equality of transportation facilities allocation is very important. These findings agree with former reports on the topic of transport-related disadvantage, which is significant not only in Australia but also in Europe, Canada, and a few Latin American countries [80-82].

Table 3 indicates that imbalanced medical facilities (medical resources) is another important factor of LAR conflict (mis-classification error rate of HP: 20.9\%). There is a good relationship between medical facilities allocation and LAR conflict. Hospitals and basic medical facilities are in a state of shortage, and residents are anxious about living near hospitals. Under the medical demand preference for a sense of security, LAR can enhance their basic rights in the social space [83,84]. Results have certified that residents within a $200 \mathrm{~m}$ range of hospitals are optimistic about replacing their residence through LAR to obtain an improved living environment. This is because it is easy for residents to experience a classical conditioning effect because hospitals cannot provide customers with a pleasant 
experience. Residents regard hospitals as "disease centers" and believe that being near hospitals would increase the risk of being infected with diseases. In addition, it should be noted that an intensive traffic flow near hospitals can be observed with considerable congested transportation and increased time in traffic jams. This accounts for the relationship between the spatial inequality of districts within $200 \mathrm{~m}$ of medical facilities and LAR conflict. By contrast, the non-conflict LAR cases were determined to be concentrated within the 200-800 m range of medical resources (e.g., AAA-level hospitals), in which all of Hangzhou City's high-quality medical resources are concentrated (e.g., the districts of Shangcheng, Xiacheng, and West Lake). This can be explained by the fact that the frequently use of medical resources with respect to individual residents is lower than that of educational and transportation resources. People have limited demand for medical resource accessibility. It denotes that characterizing the spatial equality of medical facilities allocation is very important. This is the same as the US where a big issue is the inequitable geographic distribution of health care resources [85].

Table 3 indicates that imbalanced leisure facilities allocation is another important factor of LAR conflict (mis-classification error rate of RV: $28.6 \%$ ). There is a good relationship between leisure facilities allocation and LAR conflict. Water resources are an important material foundation and a basic guarantee for human social production. Residents have attracted increasing considerable attention in terms of leisure time and water resources, which constitute an urban ecological landscape system with substantially high ecological value [86,87]. In our study region, the implementation of the water treatment plant in Zhejiang Province has resulted in the significant improvement of rivers. The hydrophilic preference of the Hangzhou City residents is increasingly significant. People are inclined to live closer to nature (e.g., water resources), which will make them less stressed and far away from mental health problems. Thus, residents who live within $600 \mathrm{~m}$ of a river have the advantages of "place-based" water resources, which increase the ecological services of the natural environment and effectively improve the environment. Therefore, advantaged groups strive to equitably share the spatial resources and enjoy the city's public infrastructure and basic public services. People are challenged by the spatial deprivation of leisure facilities and then LAR conflicts occur [87]. This accounts for the relationship between the spatial deprivation of leisure facilities and LAR conflict. It denotes that characterizing the spatial equality of leisure facilities allocation is very important.

Table 3 indicates that imbalanced educational facilities allocation is another important factor of LAR conflict (mis-classification error rate of SC: $20.7 \%$ ). There is a good relationship between educational facilities allocation and LAR conflict. In our study, Hangzhou City has high-quality and extensive educational resources; however, these resources are unevenly distributed in space, with most being located within the old city. As shown in our study, residents within a $400 \mathrm{~m}$ range of schools are sensitive to LAR. This is because for individuals and families education is the best way to achieve high economic achievement at a larger scale [88]. In China, educational opportunities depend on schools, districts, and states. Actually, educational resources are divided based on the principle of proximity. Many researchers have reported that there are good relationships between the unequal distribution of educational facilities and the unequal educational opportunities [88-90]. Therefore, residents who face LAR near schools worry about losing high-quality educational resources. Under the preference for high-quality education for advantaged educational groups, residents are inclined to take measures to eliminate the spatial deprivation of educational resources and resist LAR, and even become "a nail household" to safeguard their own interests. This accounts for the relationship between the spatial deprivation of districts within $400 \mathrm{~m}$ of schools and LAR conflict. It indicates that characterizing the spatial equality of educational facilities allocation is very important. These findings are echoed by the phenomenon that the distribution of educational facilities are a spatial injustice worldwide $[2,88,91,92]$.

\subsection{Guidance Policy}

Urban public resources allocation are spatially unequal, and how to maximize the accessibility and minimize the social and spatial inequities should be noted by LAR policymakers [93]. The government needs to optimize infrastructure, particularly balanced urban public resources allocation (e.g., ER, HP, 
$\mathrm{RV}$, and SC), to enable the different space groups to equitably enjoy urban public infrastructure and basic public services. Society shares the gains obtained by space production-focused urbanization, and the appeal of excessive location conditions could be decreased. The research findings indicate that areas within a $1 \mathrm{~km}$ radius of elevated roads and areas within a $200 \mathrm{~m}$ range of hospitals are characterized as the spatial inequality of elevated roads and hospital allocation and prone to LAR conflicts. Therefore, the government should enhance guidance for the planning and construction of such balanced infrastructure from the perspective of transportation and medical facilities. All of the infrastructure should be allocated at as great a distance as possible from residential areas, and an appropriate buffer zone around these areas should be established to reduce the residents' concerns. In addition, the river landscape infrastructure within $600 \mathrm{~m}$ and the basic education resources within $400 \mathrm{~m}$ have positive effects on the surrounding residents. The government should provide a good environment by expanding the scope of its services to share the spatial justice of urban public facilities allocation, such as improving the traffic accessibility of the river landscape and sharing basic education resources.

Moreover, regional differentiation compensation policies should be developed under the guidance of the spatial injustice of urban public facilities allocation. A compensation priority should be established to resolve accumulated social conflicts and crises caused by the unbalanced urban public facilities allocation. In our study, the residents within a $600 \mathrm{~m}$ radius of a river and residents within a $400 \mathrm{~m}$ range of schools are sensitive resource allocation groups who must face the spatial deprivation of water resources and educational resources. Local government is recommended to focus on the spatial justice of urban public resources and propose some regionally different guidance policies. Additionally, the compensation standard should be changed according to the differences in accessibility of the influencing urban public facilities. All these procedures could enhance the fundamental rights of people who have been deprived of their advantageous geographical conditions during LAR. Therefore, all people are able to share in the gains obtained by space production-focused urbanization and achieve an optimized allocation of space resources.

\section{Conclusions}

China has witnessed substantial LAR with the country's rapid urbanization and industrial development. However, there are unequal urban public resources allocations that contribute to spatial injustice in service provision and exacerbate LAR conflicts. This study re-interpreted the influencing factors of LAR conflict from the perspective of the spatial injustice of urban public facilities allocation in Hangzhou City by examining 195 administrative litigation cases. Five aspects and 10 factors of urban public facilities allocation were selected. A CART model was applied to explore the determinant factors and their interrelationship with LAR conflicts. We find that LAR conflicts lie on the spatial mismatch between the spatial behavior preferences of human activity and the spatial distribution of urban public resources. Areas within a $1 \mathrm{~km}$ radius of elevated roads and areas within a $200 \mathrm{~m}$ range of hospitals are prone to have no LAR conflicts. While residents within a $600 \mathrm{~m}$ radius of a river and residents within a $400 \mathrm{~m}$ range of schools are sensitive allocation groups, facing the spatial deprivation of water resources and educational resources. Some effective policies have been proposed to achieve sustainable development by regulating the spatial injustice of urban public resources allocation associated with LAR. However, this study only considers the spatial justice of urban public facilities at a spatial scale. Whether the LAR conflict have spatial auto-correlation is not known. In addition, this study only investigated Hangzhou City; thus, similar studies on other regions (e.g., the entire Zhejiang Province) should be conducted to understand the spatial justice of urban public resources allocation. These comparisons in future would contribute to gaining a comprehensive understanding of LAR conflicts at different scales.

Acknowledgments: The authors are grateful for the financial support from Zhejiang Provincial Social Science Foundation of China (16NDJC145YB); National Science-Technology Support Plan Project, China (41501190; 
71503228); Key national statistical scientific research projects (2017545); Zhejiang Provincial Natural Science Foundation Of China (LQ18D010005); and Social Science Foundation of Hangzhou (Z18JC050, Z18JC051).

Author Contributions: J.Z. and H.B. designed the study; Q.X. and Y.Pa. performed the analysis; J.Z. and Y.Pa. contributed data; J.Z. and Q.X. wrote the paper; Y.Pe. and L.F.Q. contributed to the writing.

Conflicts of Interest: The authors declare no conflict of interest.

\section{References}

1. Zhang, Y.; Chen, Z.; Cheng, Q.; Zhou, C.; Jiang, P.; Li, M.; Chen, D. Quota restrictions on land use for decelerating urban sprawl of Mega city: A case study of Shanghai, China. Sustainability 2016, 8, 968. [CrossRef]

2. Shan, L.P.; Yu, A.T.W.; Wu, Y.Z. Strategies for risk management in urban-rural conflict: Two case studies of land acquisition in urbanising China. Habitat Int. 2017, 59, 90-100. [CrossRef]

3. Lunstrum, E. Green grabs, land grabs and the spatiality of displacement: Eviction from Mozambique's Limpopo National Park. Area 2016, 48, 142-152. [CrossRef]

4. Oliveira, G. Land regularization in Brazil and the global land grab. Dev. Chang. 2013, 44, 261-283. [CrossRef]

5. Horman, C.; Orleans, M. The urban land question in Africa: The case of urban land conflicts in the city of Lusaka, 100 years after its founding. Habitat Int. 2015, 48, 209-218.

6. Shen, L.Y.; Peng, Y.; Zhang, X.L.; Wu, Y.Z. An alternative for evaluating sustainable urbanization. Cities 2012, 29, 32-39. [CrossRef]

7. Peng, Y.; Lai, Y.N.; Li, X.W.; Zhang, X.L. An alternative model for measuring the sustainability of urban regeneration: The way forward. J. Clean. Prod. 2015, 109, 76-83. [CrossRef]

8. Bao, H.J.; Zhu, X.T.; Cen, Y.Y.; Peng, Y.; Xue, J.B. Effects of social network on human capital of land-lost farmers: A study in Zhejiang province. Soc. Indic. Res. 2017, 1-21. [CrossRef]

9. Wu, F. China's eco-cities. Geoforum 2012, 43, 169-171. [CrossRef]

10. Yang, D.Y.R.; Wang, H.K. Dilemmas of local governance under the development zone fever in China: A case study of the Suzhou region. Urban Stud. 2008, 45, 1037-1054. [CrossRef]

11. Kaida, N.; Miah, T. Rural-urban perspectives on impoverishment risks in development-induced involuntary resettlement in Bangladesh. Habitat Int. 2002, 50, 73-79. [CrossRef]

12. Tong, W.M.; Zhang, P.Y.; Lo, K.; Chen, T.T.; Gao, R. Age-differentiated impact of land appropriation and resettlement on landless farmers: A case study of Xinghua village, China. Geogr. Res. 2017, 55, $293-304$. [CrossRef]

13. Hui, E.C.M.; Bao, H. The logic behind conflicts in land acquisitions in contemporary China: A framework based upon game theory. Land Use Policy 2013, 30, 373-380. [CrossRef]

14. Bao, H.; Cen, Y.; Peng, Y.; Yuan, D. Entrepreneurship and Intervention Strategies of Land-Lost Farmers in Urbanization Process of Zhejiang Province. Public Pers. Manag. 2016, 45, 37-57. [CrossRef]

15. Ren, X.F. Land acquisition, rural protests, and the local state in China and India. Environ. Plan. C 2017, 35, 25-41. [CrossRef]

16. Beijing Cailiang Law Firm. Annual Report of Urban Housing Demolition in China. 2015. Available online: http:/ / www.cai-liang.com/view.asp?1911.html (accessed on 27 February 2016). (In Chinese)

17. Yu, T.; Shen, G.Q.P.; Shi, Q.; Zheng, H.W.Z.; Wang, G.; Xu, K.X. Evaluating social sustainability of urban house demolition in Shanghai, China. Habitat Int. 2017, 153, 26-40.

18. Liu, Y. Government monopoly, dual-track system and excess land requisition: A theoretical and empirical study on the reform from land requisition through negotiation to land requisition through public notification. Mod. China Stud. 2013, 20, 131-177.

19. Guo, X. Land expropriation and rural conflicts in China. China Q. 2001, 166, 422-439. [CrossRef]

20. Yep, R.; Fong, C. Land conflicts, rural finance and capacity of the Chinese state. Public Adm. Dev. 2009, 29, 69-78. [CrossRef]

21. Bao, H.J.; Ye, Q.Y.; Xu, S.M. Conflict and governance of rural collectiveowned land Expropriation: An interdisciplinary literature comment. China Land Sci. 2014, 28, 82-88.

22. Barry, M.B.; Dewar, D.; Whittal, J.F.; Muzondo, I.F. Land conflicts in informal settlements: Wallacedene in Cape Town, South Africa. Urban Forum 2017, 18, 171-189. [CrossRef] 
23. Zhu, Y. China's floating population and their settlement intention in the cities: Beyond the Hukou reform. Habitat Int. 2007, 31, 65-76. [CrossRef]

24. De Haas, H. Migration and developments: A theoretical perspective. Int. Migr. Rev. 2010, 44, $227-264$. [CrossRef] [PubMed]

25. Zhu, Y.; Chen, W. The settlement intention of China's floating population in the cities: Recent changes and multifaceted individual-level determinants. Popul. Space Place 2010, 16, 253-267. [CrossRef]

26. Tang, S.; Feng, J. Cohort differences in the urban settlement intention of rural migrants: A case study in Jiangsu Province. Habitat Int. 2015, 49, 357-365. [CrossRef]

27. Long, H.L.; Li, Y.R.; Liu, Y.S.; Woods, M.; Zou, J. Accelerated restructuring in rural China fueled by 'increasing vs. decreasing balance' land-use balance policy for dealing with hollowed villages. Land Use Policy 2012, 29, 323-333. [CrossRef]

28. Chen, Z.G.; Wang, Q. Economic growth, market-oriented reforms and illegal activities on land use, China Population. Resour. Environ. 2013, 23, 48-54.

29. Gong, J.; Chen, W.; Liu, Y. The intensity change of urban development land: Implications for the city master plan of Guangzhou, China. Land Use Policy 2014, 40, 91-100. [CrossRef]

30. Ding, C. Policy and praxis of land acquisition in China. Land Use Policy 2007, 24, 1-13. [CrossRef]

31. Johnson, M.P.; Hollander, J.; Hallulli, A. Maintain, demolish, re-purpose: Policy design for vacant land management using decision models. Cities 2014, 40, 151-162. [CrossRef]

32. Chen, Z.G.; Wang, Q.; Chen, Y.; Huang, X.J. Is illegal farmland conversion ineffective in China? Study on the impact of illegal farmland conversion on economic growth. Habitat Int. 2015, 49, 294-302. [CrossRef]

33. Cynthis, S.S.; Stephen, P.; Marcos, A.P.; Luiz, G.T.S. The changing dynamics of land conflict in the Brazilian Amazon: The rural-urban complex and its environmental implications. Urban Ecosyst. 2002, 6, 99-121.

34. Wang, H.; Tao, R.; Wang, L.L.; Su, F.B. Farmland preservation and land development rights trading in Zhejiang, China. Habitat Int. 2010, 34, 454-463. [CrossRef]

35. Dadashpoor, H.; Rostami, F.; Alizadeh, B. Is inequality in the distribution of urban facilities inequitable? Exploring a method for identifying spatial inequity in an Iranian city. Cities 2016, 52, 159-172. [CrossRef]

36. Soja, E. Seeking Spatial Justice; University of Minnesota Press: Minneapolis, MN, USA, 2010.

37. Green, B.; Letts, W. Space, equity, and rural education: A 'trialectical' account. In Spatial Theories of Education: Policy and Geography Matters; Gulson, K.N., Symes, C., Eds.; Routledge: Abingdon, UK, 2007; pp. 57-76.

38. Dabinett, G. Spatial justice and the translation of European strategic planning ideas in the urban sub-region of south Youkshire. Urban Stud. 2010, 47, 2389-2408. [CrossRef] [PubMed]

39. Witten, K.; Exeter, D.; Field, A. The quality of urban environments: Mapping variation in access to community resources. Urban Stud. 2003, 40, 161-177. [CrossRef]

40. Chang, H.S.; Liao, C.H. Exploring an integrated method for measuring the relative spatial equity in public facilities in the context of urban parks. Cities 2011, 28, 361-371. [CrossRef]

41. Xiao, Y.; Wang, Z.; Li, Z.G.; Tang, Z.L. An assessment of urban park access in Shanghai-Implications for the social equity in urban China. Landsc. Urban Plan. 2017, 157, 383-393. [CrossRef]

42. Lee, G.; Hong, I. Measuring spatial accessibility in the context of spatial disparity between demand and supply of urban park service. Landsc. Urban Plan. 2013, 119, 85-90. [CrossRef]

43. Rigolon, A. A complex landscape of inequity in access to urban parks: A literature Review. Landsc. Urban Plan. 2016, 153, 160-169. [CrossRef]

44. Tsou, K.W.; Hung, Y.T.; Chang, Y.L. An accessibility-based integrated measure of relative spatial equity in urban public facilities. Cities 2005, 22, 424-435. [CrossRef]

45. Golubchikov, O.; Deda, P. Governance, technology and equity: An integrated policy framework for energy efficient housing. Energy Policy 2012, 41, 733-741. [CrossRef]

46. Hall, S.M.; Hards, S.; Bulkeley, H. New approaches to energy: Equity, justice and vulnerability, Introduction to the special issue. Local Environ. 2013, 18, 413-421. [CrossRef]

47. Rosero-Bixby, L. Spatial access to health care in Costa Rica and its equity: A GIS-based study. Soc. Sci. Med. 2004, 587, 1271-1284. [CrossRef]

48. Pearce, J.R.; Richardson, E.A.; Mitchell, R.J.; Shrtt, N.K. Environmental justice and health: The implications of the socio-spatial distribution of multiple environmental deprivation for health inequalities in the United Kingdom. Trans. Inst. Br. Geogr. 2010, 35, 522-539. [CrossRef] 
49. Smith, N.; Mitton, C.; Hall, W.; Bryan, S.; Donaldson, C.; Peacock, S.; Gibson, J.L.; Urquhart, B. High performance in healthcare priority setting and resource allocation: A literature- and case study-based framework in the Canadian context. Soc. Sci. Med. 2016, 162, 185-192. [CrossRef] [PubMed]

50. Yu, A.T.W.; Wu, Y.Z.; Shen, J.H.; Zhang, X.L.; Shen, L.Y.; Shan, L.P. The key cause of urban-rural conflict in China. Habitat Int. 2015, 49, 65-73. [CrossRef]

51. Fuente, H.D.L.; Rojas, C.; Salado, M.J.; Carrasco, J.A.; Neutens, T. Socio-Spatial Inequality in Education Facilities in the Concepción Metropolitan Area (Chile). Curr. Urban Stud. 2013, 1, 117-129. [CrossRef]

52. Grant, C.A.; Arcello, A.F.; Konrad, A.M.; Swenson, M.C. Fighting for the 'right to the city': Examining spatial injustice in Chicago public school closings. Br. J. Sociol. Educ. 2014, 35, 670-687. [CrossRef]

53. Talen, E. School, Community, and Spatial Equity: An Empirical Investigation of Access to Elementary Schools in West Virginia. Ann. Assoc. Am. Geogr. 2001, 91, 465-486. [CrossRef]

54. Gao, Y.; He, Q.S.; Liu, Y.L.; Zhang, L.Y.; Wang, H.F.; Cai, E.X. Imbalance in Spatial Accessibility to Primary and Secondary Schools in China: Guidance for Education Sustainability. Sustainability 2016, 8, 1236. [CrossRef]

55. Taleai, M.; Sliuzas, R.; Flacke, J. An integrated framework to evaluate the equity of urban public facilities using spatial multi-criteria analysis. Cities 2014, 40, 56-69. [CrossRef]

56. Singleton, A.D.; Longley, P.A.; Allen, R.; O'Brien, O. Estimating secondary school catchment areas and the spatial equity of access. Comput. Environ. Urban Syst. 2011, 35, 241-249. [CrossRef]

57. Chin, H.C.; Foong, K.W. Influence of school accessibility on housing values. J. Urban Plan. Dev. 2006, 132, 120-129. [CrossRef]

58. Lotfi, S.; Koohsari, M.J. Measuring objective accessibility to neighbourhood facilities in the city (a case study: Zone 6 in Tehran, Iran). Cities 2009, 26, 133-140. [CrossRef]

59. EI-Geneidy, A.; Levinson, D.; Diab, E.; Boisjoly, G.; Verbich, D.; Loong, C. The cost of equity: Assessing transit accessibility and social disparity using total travel cost. Transp. Res. Part A 2016, 91, 302-316.

60. Guzman, L.A.; Oviedo, D.; Rivera, C. Assessing equity in transport accessibility to work and study: The Bogotá region. J. Transp. Geogr. 2017, 58, 236-246. [CrossRef]

61. Foth, N.; Manaugh, K.; EI-Geneidy, A.M. Towards equitable transit: Examining transit accessibility and social need in Toronto, Canada, 1996-2006. J. Transp. Geogr. 2013, 29, 1-10. [CrossRef]

62. Welch, T.F.; Mishra, S. A measure of equity for public transit connectivity. J. Transp. Geogr. 2013, 33, $29-41$. [CrossRef]

63. Omer, I. Evaluating accessibility using house-level data: A spatial equity perspective. Comput. Environ. Urban Syst. 2006, 30, 254-274. [CrossRef]

64. Dadashpoor, H.; Rostami, F. Measurement of Integrated Index of Spatial Justice in the Distribution of Urban Public Services Based on Population Distribution, Accessibility and Efficiency in Yasuj City. Urban Reg. Stud. Res. J. 2011, 10, 1-4.

65. Liu, L.; Liu, J.; Zhang, Z. In search of solutions to Ethinic conflicts caused by coal mining in inner Mongolia, China. Sustainability 2014, 6, 8756-8774. [CrossRef]

66. Huang, X.J.; Li, Y.; Yu, R.; Zhao, X.F. Reconsidering the controversial land use policy of "linking the decrease in the rural land construction land with increase in urban construction land": A local government perspective. China Rev. 2014, 14, 175-198.

67. Chatterton, P. Seeking the urban common furthering the debate on spatial justice. City 2010, 14, 625-628. [CrossRef]

68. Bao, H.; Peng, Y. Effect of land expropriation on land-lost farmers' entrepreneurial action: A case study of Zhejiang Province. Habitat Int. 2016, 53, 342-349. [CrossRef]

69. Zhou, W.; Peng, Y.; Bao, H. Regular pattern of judicial decision on land acquisition and resettlement: An investigation on Zhejiang's 901 administrative litigation cases. Habitat Int. 2017, 63, 79-88. [CrossRef]

70. Dai, D. Racial/ethnic and socioeconomic disparities in urban green space accessibility: Where to intervene? Landsc. Urban Plan. 2011, 102, 234-244. [CrossRef]

71. Rigolon, A.; Flohr, T.L. Access to parks for youth as an environmental justice issue: Access inequalities and possible solutions. Buildings 2014, 4, 69-94. [CrossRef]

72. Zhou, X.; Kim, J. Social disparities in tree canopy and park accessibility: A case study of six cities in Illinois using GIS and remote sensing. Urban For. Urban Green. 2013, 12, 88-97. [CrossRef]

73. Gutiérrez, J. Location, economic potential and daily accessibility: An analysis of the accessibility impact of the high-speed line. J. Transp. Geogr. 2001, 9, 229-242. [CrossRef] 
74. Wang, J.; Yuan, H.; Kang, X.; Lu, W. Critical success factors for on-site sorting of construction waste: A China study study. Resour. Conserv. Recycl. 2010, 54, 931-936. [CrossRef]

75. Litting, B.; Griessler, E. Social sustainability: A catchword between political pragmatism and social theory. Int. J. Sustain. Dev. 2005, 8, 65-79. [CrossRef]

76. Schlosberg, D. The rising environmental justice: The expanding sphere of a discourse. Environ. Politics 2013, 22, 37-55. [CrossRef]

77. Bewes, O.G.; Thompson, D.J.; Jones, C.J.C.; Wang, A. Calculation of noise from railway bridges and viaducts: Experimental validation of a rapid calculation model. J. Sound Vib. 2006, 293, 933-943. [CrossRef]

78. Huang, J.; Lin, M.; Wong, D.C.; Wang, X.M.; Wang, B.M. On the influence of viaduct and ground heating on pollutant dispersion in 2D street canyons and toward single-sided ventilated buildings. Atmos. Pollut. Res. 2016, 7, 817-832. [CrossRef]

79. Zhang, C.F.; Wen, M.; Zeng, J.R.; Zhang, G.L.; Fang, H.P.; Li, Y. Modeling the impact of the viaduct on particles dispersion from vehicle exhaust in street canyons. Sci. China Technol. Sci. 2012, 55, 48-55. [CrossRef]

80. Lucas, K.; Jones, P. Social impacts and equity issues in transport: An introduction. J. Transp. Geogr. 2012, 21, 1-3. [CrossRef]

81. Currie, G.; Richardson, T.; Smyth, P.G.; Vella-Brodrick, D.; Hine, J.; Lucas, K.; Stanley, J.; Morris, J.; Kinnear, R.; Stanley, J.R. Investigating links between trasport disadvantage, social exclusion and well-being in Melborne-updated results. Res. Transp. Econ. 2009, 29, 287-295. [CrossRef]

82. Pyrialakou, V.D.; Gkritza, K.; Fricker, J.D. Accessibility, mobility, and realized travel behavior: Assessing transport disadvantage from a policy perspective. J. Transp. Geogr. 2016, 51, 252-269. [CrossRef]

83. Mitton, C.; Donaldson, C. Setting priorities and allocating resources in health regions: Lessons from a project evaluating program budgeting and marginal analysis. Health Policy 2003, 64, 335-348. [CrossRef]

84. Peacock, S.; Mitton, C.; Ruta, D.; Donalsdon, C.; Bate, A.; Hedden, L. Priority setting in health care: Towards guidenlines for the program budgeting and marginal analysis framework. Expert Rev. Pharmacoecon. Outcomes Res. 2010, 10, 539-552. [CrossRef] [PubMed]

85. Yang, D.H.; Robert Goerge, R.; Mullner, R. Comparing GIS-based methods of measuring spatial accessibility to health services. J. Med. Syst. 2006, 30, 23-32. [CrossRef] [PubMed]

86. Comber, A.; Brunsdon, C.; Green, E. Using a GIS-based network analysis to determine urban green space accessibility for different ethnic and religious groups. Landsc. Urban Plan. 2008, 86, 103-114. [CrossRef]

87. Salka, W.M. Urban-rural conflict over environmental policy in the western united states. Am. Rev. Public Adm. 2001, 31, 33-48. [CrossRef]

88. Coleman, J.S.; Campbell, E.Q.; Hobson, C.J.; McPartland, J.; Mood, A.M.; Weinfeld, F.D. Equality of Educational Opportunity; Government Printing Office: Washington, DC, USA, 1966.

89. Swallow, J.R.; Nielson, E.B.; Chakufyali, P.N. USAID/Zambia Education Program Evaluation; United States Agency for International Development: Washington, DC, USA, 2009.

90. Wolhuter, C.C. Education for all in sub-Saharan Africa: Prospects and challenges. In Education for All: Global Promises, National Challenges; Baker, D.P., Wiseman, A.W., Eds.; Elsevier: Amsterdam, The Netherlands, 2007; Volume 8, pp. 337-362.

91. World Bank. Education and Development; World Bank: Washington, DC, USA, 2011.

92. Clark, D.E.; Herrin, W.E. The impact of public school attributes on home sale prices in California. Growth Chang. 2000, 31, 385-407. [CrossRef]

93. Peng, Y.; Zhu, X.; Zhang, F.; Huang, L.; Xue, J.; Xu, Y. Farmers' risk perception of concentrated rural settlement development after the 5.12 Sichuan Earthquake. Habitat Int. 2018, 71, 169-176. [CrossRef]

(C) 2018 by the authors. Licensee MDPI, Basel, Switzerland. This article is an open access article distributed under the terms and conditions of the Creative Commons Attribution (CC BY) license (http://creativecommons.org/licenses/by/4.0/). 